\title{
Social Movement Uses of Capitalist Infotainment
}

\author{
JL Johnson
}

This article stems from my ethnographic research on social movement uses of infotainment styles of communication encouraged by and in a fast capitalism. A critical conversation about social movements is essentially discursive and collectivist, yet the current media landscape privileges an imagistic and personalized style of digital communication. To better understand this puzzle, I volunteered to be a communications intern for a social movement organization (SMO) working on establishing a network of straight allies of LGBT acceptance and equality. The work involved editing online correspondences, writing a blog, responding to emails, coordinating interviews with grassroots members, making fundraising phone calls, and stuffing mailers. At the urging of the staff, I attended an awards ceremony to celebrate leaders in the corporate and entertainment industries who had donated to or otherwise supported LGBT issues, where I helped set up a makeshift red carpet, staged celebrities, performed event management tasks, and recorded speeches for online dissemination.

I augmented my ethnographic work with interview data from workers in a range of SMOs that fell into three specific issue groups: LGBT advancement, food justice, and human rights. In one-hour, semi-structured, open-ended interviews, I explored how communication specialists make meaning of their work and the group constraints that act on that work. I examined the assumptions they make about how to use media and their communicative capabilities and limitations, who they imagine to be their public and not, what assumptions they hold about publics, and how communicatively effective they feel they are.

With these qualitative data, I endeavored to answer questions about the effectiveness of online social movement strategies. How and in what form do movement claims mobilize? What gives shape to online movement communications, and what are their (anti)democratic consequences? In what follows, I argue that a digital media landscape structures broad assumptions, strategies, and tactics that some movement actors make about how to mobilize online for public consideration. These assumptions, strategies, and tactics are explicitly about a public attention indelibly affected by the culture industries. I reveal the underlying assumptions and practices drawn from and resembling a capitalist media culture that mixes information, entertainment, and celebrity as a social process that shapes a certain aspect of the work social movement actors do to succeed at online communication.

To present my argument, I first summarize work done by anthropologists Rodrigo Ochigame and James Holston relating internet and digital technologies to a social movement's struggle for online publicity, what they call a "politics of audibility." Ochigame and Holston's idea of a politics of audibility is limited to computer algorithms, so I extend a politics of audibility to include their idea within a range of capitalism's broader effects on societal attention. To accomplish such an extension, I draw from the Frankfurt School to define two structural contradictions of the culture industry that produce specific templates and objects of attention that have migrated to online spaces. Although cultural industries produce constraints in a political economy of attention, capitalism's cultural forms are reassembled by social movements toward their particular ends. I analyze such processes as assemblages of "communicative fiber," and I conclude by presenting some of my qualitative data on how some social movement actors put together capitalism's communicative fiber for online attention. 


\section{Capitalist Media as a Political Economy of Attention}

Social scientists have been demonstrating since the mid-twentieth century that capitalist media make it difficult for social movements to communicate with publics. Media scholars, for example, have revealed that capitalistic assumptions about attention favor a social movement communication that is fast, imagistic, attractive, and terse. Catering to audience expectations of speed and terseness does not necessarily contradict Douglas Kellner's idea that "[p]olitical and social life is...shaped more and more by media spectacle" (2005). If anything, the ideas of critical theorists about the nearly absolute power with which screen-mediated spectacles dominate our lives continue to be relevant (Agger 1989; Luke 1989; Kellner 2003), even as these spectacles increasingly play out on smaller devices. Critical theories of media inform my research program into questions about whether and how there might be social movement constructions of media spectacles, especially those spectacles increasingly mediated by online mobile technologies that can be used for social movement purposes.

Literature on the relationship between movements and media shows that movement actors have been savvy to meet capitalist expectations of spectacle for a chance at attracting mainstream media attention to a diversity of movement issues and claims (Baker 1994; Bennett 2007; Entman 1989; Fishman 1980; Gans 1979; Gamson and Wolfsfeld 1993; Gitlin 1978, 1980; Lester 1980; Schudson 1978, 2000; Sobieraj 2011; Tuchman 1978). The prognosis from this literature has been that journalistic norms of objectivity and gathering information congeal into a journalist's beat with corporate press offices, police dispatchers, or other governmental officials. In such a state of affairs, sociologists have understood that activists conformed to capitalist media expectations of and assumptions about audience attention because of the gatekeeping function journalists have served between social movements and a society's economic and state elites, with journalists usually capitulating to the communicative terms of the former.

Social movement actors would prefer journalistic beats that treated social movements as authoritative sites of claims-making and fact-gathering, what might be called a social movement beat. In theory, social movement beats would mitigate capitalism's distortions of democratic communication. With internet technologies, resources, and planning, people in social movements increasingly have realized they might construct a social movement beat themselves. With digital tools to cover their choice issues and claims, movement actors begin to think organizationally about how to do communicative mobilization (Alexander 2006), in other words, begin assuming for themselves some of the role of news media actors. However, an open question remains about the degree to which the opening of direct access between a social movement and publics accentuates capitalism's cultural forms of communication in an infotainment society, as persistent impacts on templates, styles, and objects of communication.

This context of the availability to social movements of digital tools and internet technologies has raised questions about how media cultures continue to shape the assumptions and practices made by some movement actors about what gets online attention. Despite tech utopians heralding digital technology as enabling revolutionary democratic participations, capitalist popular culture continues to dominate and dictate mass online attention, especially seen in digital music culture (Hanrahan 2016).

I draw on anthropologists Rodrigo Ochigame and James Holston (2016), who usefully argue that computer filters are increasingly powerful determinants of attention that work against social movements. Their idea of a politics of audibility enables us to think about the non-circulation of social movement messages in online communications. Politics of audibility shape the chances of movements being heard, and they set into motion strategies to mobilize a type of communication that might rise to the top of online filters. Ochigame and Holston use the case study of how Brazilian land activists in the social movement Aty Guasu ("the great assembly") circumvented algorithmic obstacles by turning their profiles into advertisements for their movement, by changing their personal names on Facebook to "Guarani-Kaiowá," the indigenous Brazilians being displaced by private and public land grabs. By changing their names on Facebook, activists raised consciousness of the social problem, gaining online circulation and making the issue relatively well-known in their social networks. With a personalized tactic to game a politics of audibility, Aty Guasu activists made their movement very popular for a short amount of time, before Facebook banned their naming practice, ostensibly enforcing its "real name" policy.

I extend Ochigame and Holston's focus on digital (non)circulation to include a range of capitalism's broader effects on societal attention. Media objects (personal computers, algorithms, and Facebook profiles) are pieces to move around in a politics of audibility only because they are incorporated within the broader structural sources of capitalist communication. Since Ochigame and Holston rightly note that TV and print coverage often censor "the range of views available" (96), it puzzles me that they do not address how capitalism informs the cultural practices 
behind both television and computer development, programming, and reception. My extension of a politics of audibility incorporate capitalist contradictions of communication that situate a social movement's chances of being heard online into a political economy of attention, which I explain below. I turn to the Frankfurt School of Critical Theory to highlight two specific problem-areas of the culture industry's political effects on societal attention.

\section{Narrow Attention and Celebrity as Effects of Culture Industry}

The culture industries of fast capitalism do not only produce mass media for audience consumption. They also produce communicative effects on a society's attention, by encouraging objects for and styles of focus and discourse. Horkheimer and Adorno ([1944] 1972) touched on the ways that capitalism affects communication by interrogating mass media's distraction from progressive social movements as a tension between persuasion and manipulation. The culture industry provides a bevy of media to those who are excluded from a technical and capitalist elite, instilling in those alienated by capitalism a resistance to collective mobilizations that might provide redress to social inequalities. Two neglected problem-areas in relating media consumption to a society's resistance to social movements include 1) the culture industry's narrowing of attention during people's leisure time, which is related to 2) the culture industry's intense focus on celebrities. Horkheimer and Adorno articulated two structural contradictions within these problemareas, one on attention and another on celebrity, that create specific tensions for social movements trying to reach and persuade the public.

Horkheimer and Adorno argued that the culture industry encourages mimesis to the aesthetic of capitalism, a style and mode of being that is inherently antiradical. I thought of their point often during my fieldwork, as it was best evinced by interviewees making astute observations of an overall structure to digital infotainment: exponential ("exploded to the nth degree"), hyper ("scrolling" for "three-to-four seconds"), imagistic, and immediate. In strategizing for online communication, social movements struggle to reach mass audiences that spend their free time in front of mobile screens. The central point here relates to how the culture industry narrows attention "by occupying men's senses from the time they leave the factory in the evening to the time they clock in again the next morning" ([1944] 1972:130). Audiences, then, are likely to be uncomfortable with or suspicious of a communication that does not resemble capitalist media, leading Horkheimer and Adorno to remark, "And so the culture industry, the most rigid of all styles, proves to be the goal of liberalism, which is reproached for its lack of style" (131). The culture industry thus creates a structural contradiction for social movement communicators: whether and how they could meet the expectations of public attention with fast capitalism's usual sources of information and entertainment, and transform public dialogue into an engagement with discursive practices that are critical of status quos.

The culture industry produces another structural contradiction of political communication, one that rests on the notion that the celebrities of culture industry deserve more status and attention than ordinary citizens. This is an ideology that the culture industry helps to produce by making those "in the audience not only feel that they could be on the screen, but realize the great gulf separating them from it" (145). The contradiction for social movement communication involves the struggle to empower people to involve themselves in a democratic communication when they have been conditioned to defer to people with higher status. To Horkheimer and Adorno, the central point was that capitalism is partially legitimated through the culture industry's focus on celebrity. Consumers wrapped up in the culture industry conflate democracy and capitalism, confusing democracy for a lottery in which everyone has a chance to flourish, but status and attention become perceived as deservedly vested in those atop hierarchies. In my research program, I see that the system not only becomes partially legitimated through this focus on celebrity, but also produces specific practices of deferring attention and discursive authority to those with celebrity status. Online communication, at least in terms of its reliance on and emphasis of quantitative metrics of success, only exacerbates this antidemocratic logic of celebrity and popularity.

The culture industry, then, might be understood as a political economy of attention in that it affects how social movements consider their approach to reaching the public, especially affecting online strategies for attention. Similar to Marx's dictum that men make history out of circumstance not of their choosing, movement actors are free to construct any act of political communication, but they are not free to make an act of communication out of materials of their own choosing. The culture industries narrow societal attention to particular screens at particular times, affecting how and on what people give their focus. I address these effects as conditional materials with which social movements nonetheless may be effective at online communication. 


\section{Communicative Fiber: Assemblages of Capitalist Media}

A political economy of attention produces some of the more popular cultural forms of infotainment and celebrity as media objects available to be used for social movement communicative mobilization. In my research program, I develop the idea of "communicative fiber" to explain the individual processes involved in drawing from capitalism's cultural forms, especially capitalism's obsession with celebrity spectacle, to assemble specific acts of social movement publicity (Johnson 2017). I argue that communicative fiber are common cultural pieces available to social movements, what Michael Shudson analyzed as "retrievability" (1989:160), for the purposes of attracting attention, garnering sympathy, and holding together a political audience, including media pieces available for forging a specific act of political conversation. Communicative fiber includes media technologies and the forms of attention, thought, and discussion that accompany and are encouraged by those media. By defining social movement communicative fiber as the process of connecting media forms and contents, as repurposing and weaving together disparate capitalist media into political messages, I attempt to evoke an imagery of a membrane-like swirl of communication resembling a digitally mediated and messy landscape of political noise.

While market actors do attempt some bounding of what media can do in-order-to sell media products to advertisers and the largest possible audience, those contours are nonetheless malleable. Emphasizing malleability, we can avoid some of the absolutism of the Frankfurt School approach to cultural analysis without losing too much of its warranted criticism of capitalist media. There is paradoxical strength to the porousness of capitalist media's communicative boundaries, in that they limit the shape and content but not necessarily the uses of objects and modes of communication that are able to survive in a nominal democracy with capitalist infotainment media. Yet my idea of communicative fiber is anchored in a tradition of symbolic interaction; I attempt to privilege human agency by emphasizing uses, processes, and interpretation (Blumer 1969). Communicative fiber is made up of processual materials vital to the defining process that goes into constructing a political communication, but I view capitalism's production of cultural forms of communication, specifically, capitalism's effects on attention and its obsession with celebrities, to be more deterministic than most symbolic interactionists might allow.

Explicating the communicative process limited by communicative fiber borrowed from culture industries helps to explain counterfactual possibilities in capitalist societies, to bring about "reversals of media spectacles" (Kellner 2005). Even as a hybrid of televisual and digital infotainment deeply affect the form and content of our political talk online, there continue to be public issues that become articulated in the forms available to us. Certainly, Douglas Kellner is correct that "Trump's orchestration of media spectacle and a compliant mainstream media was a crucial factor in thrusting Trump ever further into the front runner status in the Republican primaries" (2017). I add that social movements of both the left and the right play their part in buttressing celebrity power in the service of activist politics. For example, the disquieting phenomenon of President Trump is that right-wing movement activists actively constructed him as a "celebrity champion" of their causes (an oxymoronic process I explain below), one that is able to meld infotainment and spectacle with an articulation of populist capitalist beliefs and white working-class anxieties in an increasingly cosmopolitanism globalism.

Communicative fiber might best relate to Nina Eliasoph's (2016) most recent project to conceptualize such puzzling, and in Trump's case troubling, forms of articulation of social problems in and through capitalism's cultural forms. I draw on Eliasoph's idea that a civil society has a disciplinarian regime of values and norms that polices people's behavior and talk, reigns in the political topics available for debate, and curtails the forms and content of civil dialogue and participation. America's civil regime, for example, favors benign volunteer clubs over explicitly political groups as appropriate voluntary associations for public life, mirroring and reinforcing capitalist media's preference for "human interest stories." Predominant communicative values that guide benign volunteer groups are hyper-individualistic, mirroring and reinforcing capitalist media's celebrity worship. America's civic regime, then, is enlivened by specific and limited communicative pieces that are actively woven together, even while being bounded by and injected with capitalist cultural forms that privilege celebrity infotainment and human interest stories in ways that determine the chances of some assemblages of communicative fiber to be heard over others. This dialectical process is best seen in my data from ethnographic fieldwork and qualitative interviews.

\section{Infotainment for Public Attention}

It had been twilight when Ramona and I stepped outside the back door of her basement level apartment in 
Washington D.C. Ramona works for Fighting Disease is Fighting Poverty (FDFP), an advocacy organization with the tagline, "The power to end poverty." Through growing public opinion, developing political will, and directing financial resources to combat health disparities that disproportionately affect the poor, FDFP aims to "end extreme poverty by the year 2030," a goal it shares with the World Bank. As a communications manager, Ramona coordinates community stakeholders and generates publicity for FDFP.

When twilight transitioned to night, Ramona lit a citronella candle. Sanguine wisps of grey smoke curl around my audio recorder, placed between us for our interview about Ramona's publicity efforts for antipoverty campaigns. Ramona tells me, "So we have these giant puppets of TB and HIV, they're giant puppets. And they walk around. Do you want to see it? I think you have to see it, to know what it looks like."

Ramona palms her smartphone, swiping her thumb across its screen, tapping it to access a digital folder of photos, and excitedly tells me about the media campaign FDFP orchestrated to raise awareness of the link between tuberculosis and poverty. Bringing up the photos, Ramona gushes, "They are like the best communications thing we've ever done." When I ask her why, she says emphatically: "Because nothing has gotten us more attention than these like, mascots."

This ethnographic scene nicely exemplifies a common answer about what would break through to potential sympathizers in fast capitalism: flashy, colorful, short, and imagistic pieces of communication. The communication directors I interviewed lamented a society full of fractured sources of information, constant flows of images, and dwindling reservoirs of attention. Tim, an executive director of the LGBT Allies Network (LAN), a national LGBT rights organization, shows this best:

What's most on the forefront for me, and for all of us in the organization, is, indeed, [people's] digital platforms, right? So I'm sitting here with my cell phone, my smart phone, and my tablet, I just left my office where my desktop was, and then... the platforms that people are accessing information, younger and younger, and more and more people are accessing a wide range of them. And I think this [holds up cell phone]? The dumbest platform is the smart phone. The dumbest, because the information has to be so concise.

Like Tim, other movement actors soberly confronted practical realities shaped by the ubiquity of mobile communications, yet remained hopeful about harnessing self-publishing tools and the unprecedented technologies and resources for controlling their messages and campaigns for people's awareness. The pressing issue is what to do about getting attention and communicating a social problem in a concise manner, working to produce what Kellner deconstructs in his idea of media spectacle: "media constructs that present events which disrupt ordinary and habitual flows of information, and which become popular stories which capture the attention of the media and the public" (2017).

Enter puppets, stage left. The irony of viruses "going viral" in Ramona's account of the publicity made with FDFP's giant puppets of HIV and tuberculosis relates to their being immediately arresting and effective in fast capitalist media. FDFP actors determined that most discussions among antipoverty activists, not to mention the public at large, ignore a core claim to which FDFP would attend ("Nobody in the HIV community ever talks about TB”). One hidden assumption about awareness is that connecting poverty to tuberculosis might grow empathy and increase the likelihood that antipoverty efforts would focus on eradicating a specific disease that affects poorer communities. These are serious and complicated issues. But Ramona's story also reveals an unspoken assumption that communicating the interrelationships between poverty, tuberculosis, and HIV is neither easy nor fun, so the unseen power of an image of tall colorful puppets of the HIV and TB viruses lies in their accessibility. Accompanied by the slogan "Deadly Duo," the puppets quickly and entertainingly advance FDFP's core claim that HIV and TB are correlated. At first blush, the idea of two roving puppets is infantile. However, something else operates beneath the surface of success stories about attention. Though seemingly contrary to the seriousness of the issue of poverty, the puppets make bare the more serious issues of movement expectations and assumptions of how people want to see and hear complicated information, particularly on mobile devices.

Individual attention, however, becomes formed through social psychological processes embedded in media as a major agent of socialization. Horkheimer and Adorno were concerned that mediated processes of socialization caused conformity and subjugation in capitalist subjects. As a sociologist reading their work, I am struck by their underappreciated structural analysis of what that process looks like in everyday life, sitting in front of screens during leisure time to relax from, forget about, and become reenergized for labor. Tim above evokes the evolution of screen-obsessed practices from the movie and television screens to "the [digital] platforms that people are accessing information, younger and younger, and more and more people are accessing a wide range of them." The evidence 
here is of the culture industry's continuing effects on people's practices with capitalist media, helping us to understand the ways that these movement actors feel pressure to mimic the aesthetic of capitalism and deliver their messages through the screens that capture most people's attention.

Audiences socialized in and expectant of fast media infotainemt are likely to be suspicious of communication that does not resemble capitalist media. The implicit connection between Ramona's puppets and Tim's lament about society's narrowing of attention is how they could meet the expectations of public attention with fast capitalism's usual sources of information and entertainment in a way that advances some aspects of public dialogue toward a nuanced understanding of social problems. Short bursts of colorful spectacles in digital media might capture, if not hold, public attention just because they meet expectations of infotainment. A structural contradiction, however, exists between infotainment and democratic communication. In my field work, a "deep dive" was a metaphor for attracting an audience and deepening its involvement. As a phrase, a "deep dive" consisted of online strategies to string together pieces of infotainment in a way that, once connected, might deepen both empathy for and critical understanding of a movement's communication.

If movement workers struggle in the kinetic nature of digital materials by operationalizing capitalist media's logic of infotaintment, they do so paradoxically, in pursuit of nuanced information. For example, in the following, Ronald of LAN likens the use of infotainment as "pipelining into a deep dive." If only movements can focus enough attention (what Ronald means by "pipelining"), the issues are covered well online. These strategies and tools enable a "deeper dive" for potential sympathizers:

I can sleep at night knowing that when you put it all together, we're telling a truth, or a set of truths, that are real. So some of them, in the same way that we're using, um, Facebook, Instagram, and some other performances to focus on certain issues [means that] certain people won't ever go to our website. We have to target our messaging, it's not to say that, that's the only thing that is real. It's to say this is, it's a pipeline. And our hope is that we have enough information and content there that they don't have to, but maybe they will want to do a deeper dive. And we have other resources for the deeper dive.

There is much to analyze in this quote. Ronald invokes the terms "a set of truths," "pipeline," and "deeper dive" to indicate two things uneasily reconcilable: a piece of a truth and the fuller context of the truth. Consider that, amidst President Trump's anxious brouhaha over comparisons of his inauguration crowd to President Obama's record crowds in 2008, Trump's communications director, Kellyanne Conway, infamously used the phrase "alternative facts" to argue against photographic evidence and insist falsely that Trump's audience was larger than Obama's. Journalists became irate by the utter falsehood of such a claim in the face of mounting evidence otherwise, but I heard in Conway's appeal echoes of Ronald saying LAN tried to inform allies of "a set of truth" about LGBT issues. The phrase seems to suggest that there is no one truth. Conway and Ronald further echo each other's point about the potential manipulation of facts and the difficulty of facing objective criticism in capitalist infotainment.

In our interview, Ronald was concerned that breaking up LAN's claims into small infotainment pieces for online dissemination would be unjust to a nuanced discussion of LGBT inequality. For example, later in our discussion, he would tell me about a 1990s biopic that heavily edited the character of a young gay man, whom he knew to be more complex, a drug user who self-medicated a depression caused by his family's rejection. The movie's message, instead, focused on and celebrated his mom, who after her son's suicide became an LGBT ally. Compared to Conway, who intentionally brokered in untruth, Ronald was musing about the effects of fragmented information on public understanding of far more complex realities around social problems. Yet he emphasized that if you put all of LAN's communications together, there is nuance and complexion - an ultimately true story of the connections among the full range of issues facing the LGBT community. A "deeper dive" evokes the ability for the internet to deliver a rich and nuanced account of news and information, an opportunity for anyone to become immersed in democratic information about a social movement. To Ronald, the 1990s biopic functioned similarly to any piece of social media communication. It might present some misinformation, but smaller pieces, inevitably specious in their narrowness, were necessary points of a delivery system. Though any decontextualized bit of information might be presented as an "alternative fact," Conway's noxious phrase for presenting unwarranted claims, Ronald is committed to a singular truth, even if broken up into pieces of movement information that are laid out as bread crumbs to a movement. Each piece could function as a "pipeline" across the vast media ecosystem, that is, each piece might be woven into others for a way to deliver potential allies to the movement's fuller communication.

In more analytic terms, infotainment styles like colorful puppets and imagistic social media posts serve as pieces to assemble for social movement communication. The strategizing and agenda-setting of laying out social movement infotainment is done as an assemblage that, when taken together with an SMO's fuller offering of communicative 
resources, is considerably more critical. However, as a political economy of attention shapes these assemblages of communicative fiber, the media landscape becomes a constructed space of online spectacles, an arms race to quicker, flashier, more immediately impactful hooks. One of the more contradictory solutions to breaking through the digital noise that I observed in my work was to rely even further on capitalist modes of visibility, specifically celebrity worship. The term "celebrity champion" was evoked as a communicative process to recruit or otherwise utilize sports stars or Hollywood actors who might lend their name, high status, visibility, and other symbolic resources to the task of garnering attention to social causes. I turn to the second problem-area of social movement uses of capitalist infotainment for democratic communication, a structural contradiction of leveraging individual celebrity status for societal attention to public issues.

\section{Mobilizing Celebrities}

Toward the end of my ethnographic fieldwork at LAN, I observed an awards ceremony for celebrity champions of LGBT ally causes, where I helped set up a makeshift red carpet, stage celebrities, do event management tasks, and make a last-minute video-recording of speeches. I took jottings in between work tasks, and from these jottings generated the following fieldnote on LAN's interaction with celebrity champions:

Tim, LAN's executive director, hovers beside a cameraman. I have come to understand that Tim sees as part of his job the need to maintain a semblance of intimacy with LAN's corporate partners, thanking them for being here. Now Tim is subtly guiding a vice president of a major accounting corporation by the arm to face the cameraman for a photo with LAN's logo. After the photo, Ronald's assistant cups his ear. Ronald nods, politely excuses himself to Peter, and briskly marches toward escalators to the hotel lobby.

Ronald returns with Jill Soloway, an Emmy-nominated Hollywood writer and director. She wrote and directed a television show about how she and her family experienced her father's coming out as transgender. It was purchased and digitally distributed by Amazon, and tonight LAN is awarding her for being a celebrity ally of LGBT issues, for transforming her personal life into the honest portrayals of LGBT struggle and acceptance featured on her show. Tim motions to the cameraman, and they have their photo taken.

I catch Tim say to Jill Soloway, “Jill, I want to introduce you to Betty." It's only now that I realize Ellen DeGeneres' mom is at the gala. Jill and Betty chat, while Tim, with his right arm gently at Jill's elbow, subtly motions to the cameraman. Standing before the white screen at a different angle, the cursive red of "Johnson \& Johnson" reads behind their left shoulders. From here you can see the purple shadow-lettering brand logo of an accounting corporation on their right, "KPMG". Above Megan and Betty's heads are LAN’s gold and magenta logo, “The Let's Get Equality Gala.”

Getting celebrities to be "champions for change" is part of some social movements' work for attention, and by extension a part of movement communicative mobilization. Ochigame and Holston (2016) argue that wellfunded organizations are advantaged over smaller groups, especially grassroots groups, trying to make progressive change, with the resources to pay for social media sites to feature their work, or to attract (and compensate) the kind of celebrity partnerships that disproportionately garner attention online. It might be that the groups I accessed, located in D.C., were a unique subset of movement groups in the overall arena, with some amount of resources to resemble corporations (Dauvergne and LeBaron 2014). Those resources variably supported a range of tasks for communications directors trying to develop celebrity champions. The cultural imaging work seen above, however, served as a symbolic kind of celebrity resource development. At the event, we endeavored to represent a mainstream coziness to celebrities and major corporations, for easily disseminated images that would capture the symbolism of successful capitalist inclusion for and celebrity acceptance of LGBT people.

It is difficult to imagine that Horkheimer and Adorno would be anything but dismissive of LAN's photo opportunities with celebrities and corporate logos. The second problem-area of the Frankfurt School that informs my work relates to how social movements borrow from the culture industry's intense focus on celebrities. The culture industry's generation of and emphasis on celebrity status produces a structural contradiction for democratic communication. Movement communicators and celebrities alike may wish to lend a celebrity's disproportionate attentional status to social issues, knowing full well that they "are the only human beings today who can serve as sacred objects, emblems of the collective consciousness of any considerable part of society" (Collins 2004:280). However, by mimicking the ways that Hollywood makes those "in the audience not only feel that they could be on 
the screen, but realize the great gulf separating them from it" (Horkheimer and Adorno [1944] 1972:145), social movements fail to question how capitalism is partially legitimated through the culture industry's focus on celebrity. More worrisome is that movements compromise, intentionally or not, the communicative authority of a public in deference to the status and attention vested in those atop entertainment hierarchies.

One does not need to go as far as Stephen Marche (2017), who compellingly assessed the Trump administration in the Los Angeles Review of Books, "The United States has become a histriocracy. We are ruled by celebrity." We do need to examine how and why online communication, through its reliance on and emphasis of quantitative metrics of success, structures the qualitative work done by social movements to conflate celebrity and political discursive authority. Brenna of Fighting Disease is Fight Poverty (FDFP) reflected an odd craftsmanship to the work of getting celebrities, noting that her organization is "not to the point of being ready to ask something like that, how to get them really involved and to be champions." Tori of Food Justice on Wheels "certainly tried to get" Michelle Obama, Oprah Winfrey and Gwyneth Paltrow, because "they amplify your voice," "that increases your reach," "you never know who's going to get a nibble from something that's out there." Ramona, also of FDFP, "assembled proposals" for Whoopi Goldberg "with a menu of options of ways she could engage with us, from like the very small to the very big."

Some scholars will deride the notion of SMO craftsmanship to build "celebrity champions for change," including myself at different moments of my own research. The point, however, relates to the ways that a social structure of the new media landscape increasingly pressures social movements into Faustian deals for online attention. Leveraging celebrity visibility in the online media landscape has been successful for both Occupy (Tom Morello of the rock group Rage Against the Machine) and Black Lives Matter (the filmmaker Quinten Tarantino, academic and popular author Cornel West). For example, the National Basketball Association became a crucial site of movement visibility for BLM in large part because Lebron James—needless to say, one of the most recognized celebrities on the planethas used his smartphone to become one of BLM's most outspoken supporters, by amplifying his work to organize boycotts of mandatory warm-up suits, leading teammates in shows of solidarity with BLM. After Travon Martin's murder, James and the Miami Heat wore black hoodies like the one worn by Martin on the night he was killed by a white vigilante. Arguably, Colin Kaepernick, the quarterback of the San Francisco 49ers, singlehandedly infused the 2016 presidential campaign coverage with BLM topics, as well as reactionary anger at celebrity activism, ironically peddled by the Tea Party's own celebrity champion, the star from "[t]he most popular U.S. reality TV show of 2004, The Apprentice," a "super capitalist, firing young would-be corporate executives in a harsh Darwinian competition to work for the eccentric and money and power obsessed mogul, The Donald" (Kellner 2005).

We are overwhelmed daily with millions of bits of infotainment, yet celebrities still garner a disproportionate amount of attention to their online presence. They leverage offline popularity into very high numbers of online followers and overwhelmingly dominate digital media and, in a trend nearing its apotheosis, politics. For movement communicators, this reality is revealed in language like "amplify" and "reach." However, generating celebrity-based publicity takes careful, and oftentimes mysterious work, and it is highly unpredictable, as Ramona reveals when she says she has "no internal knowledge of how to do that," but well-resourced "organizations like the One campaign, they just know how to do that sort of stuff."

I am not suggesting that these movement actors are solely focused on leveraging celebrities for mere attention. The trend is much more worrisome than that. These actors see "honoring someone who is famous" as movement media advocacy forged in capitalism's cultural forms of attention and celebrity. Celebrity champions are staging opportunities for visuals and issue-specific statements to potentially reach "literally billions of potential readers and viewers." Again, these elements constitute communicative fiber, revealed in the language movement actors use about their work and goals, in that an SMO leverages a celebrity's offline status for online attention for the purposes of garnering sympathy, and holding together a movement's political audience.

\section{Conclusion}

I am emphasizing two problem-areas for social movements mimicking the culture industry's expectations of and assumptions about audience attention. To activists, the lament has been that civil society would be better with a social movement beat. Today, SMO actors have realized they can make the beat themselves. However, they quickly confront expectations of ubiquitous mobile digital platforms, shaping specific communicative strategies movement 
actors make when they go about considering the attention of their audiences and how to capture it.

A political economy of attention creates a particular struggle with capitalism's communicative fiber to generate movement publicity, revealing the process of assembling communicative fiber as the social mechanisms that help us explain why and how a social movement communication continues to be formed as capitalist infotainment. By operationalizing capitalism's communicative fiber, some social movements assume the solution is to pursue critical, nuanced information for narrow audiences (the deeper dive), by catching attention with celebrity and infotainment and training it onto SMO self-publications (the meaning of pipelining). Above, Ramona's communicative work with colorful puppets of HIV and TB is recollected not just because it is a quick piece of imagistic online media. Rather, it is astonishing to her that the nuance of TB's relationship to poverty got some traction across a stretched and distracted political economy of attention. Assumptions about the media landscape shaping what audiences would pay attention to-exponential, hyper, imagistic, and immediate-do not seem to enable a complex message to get into public dialogue, yet the puppets, while meeting expectations of capitalist infotainment, seemed to do just that.

I have argued that capitalism's political economy of attention is slightly deterministic of individual processes of weaving communicative fiber into a form that might capture, but not necessarily hold, public attention. Wondering about a social movement publicity based in popular cultural forms, I determined that mobilizing celebrities further mixes entertainment and activism, shaping a certain aspect of the work movement actors do to realize communicative mobilization. Staging mediatized online situations with celebrities was discursive and interactional work, a mix of capitalist event-planning and preparing visuals for social media. The work of mobilizing celebrities involves use of infotainment for constructing mediatized spectacles for digital circulation in ways that amplify traditional protest activity, but like the inability to control what celebrities say in public, it was not clear who was in control of the broader issue of the nominally democratic conversations struck in a capitalist infotainment society.

\section{References}

Agger, Ben. 1989. Fast Capitalism. Urban: University of Illinois Press.

Alexander, Jeffrey. 2006. The Civil Sphere. NY and London: Oxford University Press

Baker, C. Edwin. 1994. Advertising and a Democratic Press . Princeton: Princeton University Press.

Bennett, W. Lance. 2007. News: The Politics of Illusion . New York: Pearson Longman.

Blumer, Herbert. 1969. Symbolic Interactionism: Perspective and Method. Berkeley, Los Angeles and London: University of California Press.

Collins, Randal. 2004. Interaction Ritual Chains . New Jersey: Princeton University Press.

Dahlberg, Lincoln. 2011. "Re-Constituting Digital Democracy: An Outline of Four Positions." New Media Society 13:885.

Dauvergne, Peter, and Genevieve LeBaron. 2014. Protest Inc.: The Corporatization of Activism. New York: Wiley.

Eliasoph, Nina. 2016. "The Civil Regime." 2016 Meeting of the American Sociological Association. Seattle, WA.

Entman, Robert. 1989. Democracy Without Citizens. New York: Oxford University Press.
Fishman, Mark. 1980. Manufacturing the News . Austin: University of Texas Press.

Gans, Herbert J. 1979. Deciding What's News: A Study of CBS Evening News, NBC Nightly News, Newsweek, and Time . New York: Pantheon Books.

Gamson, William A., and Gadi Wolfsfeld. 1993. "Movements and Media and Interacting Systems." The ANNALS of the American Academy of Political and Social Science 528: 114-125.

Gitlin, Todd. 1978. "Media Sociology: The Dominant Paradigm." Theory and Society. 6(2): 205-253.

1980. The Whole World is Watching: Mass Media in the Making and Unmaking of the New Left. Berkeley, Los Angeles, and London: University of California Press.

Hallin, Daniel. 1990. "Whatever Happened to the News?" Media and Values. Accessed on April 24, 2013 at http://www. medialit.org/reading-room/whatever-happened-news.

Hanrahan, Nancy Weiss. 2016. "La Découverte Musicale en Régime Numérique: Personnalisation, Popularité et Possibilité Esthétique," Pp. 65-80 in Ou Va La Musique? Numerimorphose et Nouvelles Experiences d'Ecoute. Edited by Philippe Le Guern. Paris: Presses des Mines. 
Horkheimer, Max and Theodor W. Adorno. 1972 [1944]. "The Culture Industry: Enlightenment as Mass Deception." In Dialectic of Enlightenment . New York: Continuum.

Johnson, JL. 2017. “Meet Them Where They Are': Social Movement Communication in a Culture of Personal Politics." Ph.D. dissertation, Department of Sociology, George Mason University, Fairfax, Va.

Kellner, D. (2003) Media Spectacle . London and New York: Routledge.

Kellner, Douglas. 2005 "Media Culture and the Triumph of the Spectacle.” Fast Capitalism 1(1). Accessed April 24, 2018 at fastcapitalism.org.

.2017. "Donald Trump, Media Spectacle, and Authoritarian Populism." Fast Capitalism 14(1). Accessed 06/12/2018.

Lester, Martin. 1980. "Generating Newsworthiness: The Interpretive Construction of Public Events." American Sociological Review 45:984-994.

Luke, Timothy W. 1989. Screen of Power: Ideology, Domination, and Resistance in Informational Society. Urbana: University of Illinois Press.

Marche, Stephen. 2017. "Celebrity Warfare: Image and Politics in the Age of Trump." The Los Angeles Review of Books. Accessed online at https://lareviewofbooks.org/article/celebrity-warfare-image-politics-age-trump/\# !.
Ochigame, Rodrigo, and James Holston. 2016. "Filtering Dissent: Social Media and Land Struggles in Brazil." New Left Review 99.

Schudson, Michael. 1978. Discovering the News: A Social History of American Newspapers. New York: Basic Books.

. 1989. "How Culture Works: Perspectives from Media Studies on Efficacy of Symbols." Theory and Society 18 (2):153-180.

2000. "The Sociology of News Production Revisited (Again).” Pp. 175-200 in Mass Media and Society edited by James Curran and Michael Gurevitch. London: Edward Arnold.

Sobieraj, Sarah. 2011. Soundbitten: The Perils of MediaCentered Political Activism . New York and London: New York University Press.

Tuchman, Gaye. 1978. Making News: A Study in the Construction of Reality. New York: Free Press. 